\title{
IMPLEMENTASI TEORI BELAJAR KONSTRUKTIVISTIK JEROME BRUNER DALAM PEMBELAJARAN PENDIDIKAN AGAMA ISLAM DI SMP NEGERI 9 YOGYAKARTA
}

\author{
Wibisono Yudhi Kurniawan \\ Universitas Islam Negeri Sunan Kalijaga Yogyakarta \\ wibisonoyudhikurniawan@gmail.com
}

\begin{abstract}
The effectiveness of implementation Islamic course depends on the approach that is used, moreover the constructivist learning theory can help teachers to solve learning problems. Research method that is used is observation, interview, and documentation. The aims of the research are (1) to get to know the implementation of Jerome Bruner learning theory in Islamic course. (2) To examine the supporting aspects and inhibition in the implementation of Jerome Bruner learning theory (3) To discover the problem solution in the implementation of Jerome Bruner learning theory in Islamic course. Based on the data analysis, the conclusion are: (1) the implementation of Jerome Bruner learning theory in Islamic course to create fun learning for students, and its implementation in Islamic course in VII grade of Junior High School 9 Yogyakarta has applied effectively based on the principal and the learning procedure. (2) In the implementation of Jerome Bruner learning theory has run well, hence completed with the supporting factors and inbibition factors. (3) The problem solving of Jerome Bruner learning method in Islamic course are teaching some characters in students such as self-confidence and tolerance the improvement of teachers quality through training participation, workshop, etc. also improving the students learning motivation.
\end{abstract}

Keywords: Jerome Bruner Learning Theory, Constructivist Learning, Islamic Course.

\begin{abstract}
Abstrak : Implementasi pembelajaran materi PAI yang efektif terletak pada pendekatan yang digunakan, maka dari itu teori pembelajaran konstruktivistik dapat membantu guru menyelesaikan permasalahan yang muncul ketika pembelajaran. Metode penelitian dengan observasi, wawancara, dan dokumentasi. Penelitian ini bertujuan (1) untuk mengetahui implementasi teori belajar konstruktivistik Jerome Bruner dalam pembelajaran PAI. (2) mengetahui faktor pendukung dan penghambat implementasi teori belajar konstruktivistik pada mata pelajaran PAI. (3) mengetahui upaya mengatasi masalah dalam implementasi terhadap model pembelajaran konstruktivistik yang diterapkan pada mata pelajaran PAI. Berdasarkan analisis data, disimpulkan bahwa: (1) implementasi dari materi PAI dengan menggunakan teori pembelajaran konstruktivistik Jerome Bruner membuat pembelajaran menjadi menyenangkan bagi siswa, dan dalam implementasinya pada pembelajaran PAI kelas VII di SMPN 9 Yogyakarta sudah diterapkan dengan baik sesuai prinsip dan langkah-langkah pembelajaran yang ada. (2) Dalam implementasi teori belajar konstruktivistik pada mata pelajaran PAI kelas VII di SMPN 9 Yogyakarta sudah berjalan dengan baik disertai faktor pendukung dan faktor penghambat. (3) Upaya mengatasi masalah dalam implementasi model pembelajaran konstruktivistik di dalam mata pelajaran PAI kelas VII di SMPN 9 Yogyakarta yaitu menanamkan karakter pada diri siswa seperti rasa percaya diri dan toleransi, peningkatan kualitas guru-guru melalui keikutsertaan dalam pelatihan, workshop, dan sebagainya, serta meningkatkan motivasi belajar pada siswa.
\end{abstract}

Islamika : Jurnal Keislaman dan Ilmu Pendidikan

Volume 3, Nomor 1, Januari 2021; 21-37

https:// ejournal.stitpn.ac.id/index.php/islamika 
Kata Kunci: Teori Pembelajaran Konstruktivistik Jerome Bruner, Pembelajaran, Pendidikan Agama Islam

\section{PENDAHULUAN}

Kesadaran manusia dibangun pada hakikatnya adalah untuk menjadi tinggi dan beradab, dan merupakan tujuan pendidikan yang telah banyak digagas oleh para pakar pendidikan saat ini. Cara pandang manusia diupayakan untuk mampu diubah oleh pendidikan supaya lebih bermakna untuk menyerap realitas apapun di dalam kehidupannya. Arti pendidikan di dalam konteks yang lebih mulia memiliki arti yaitu kesadaran yang dimiliki oleh manusia agar menjadi arif dan bijaksana mampu ditempatkan oleh pendidikan tersebut. Sudah barang tentu, pendidikan dalam arti yang sesungguhnya adalah ketika manusia mampu menyerap seluruh realitas yang ada di dalam lingkungannya, analisis kritis pun coba dilakukan terhadap apa yang dilihatnya sebagai sebuah gerakan perubahan yang dibangun menjadi lebih transformatif.

Sudah menjadi barang tentu, apa yang dimaksudkan di atas adalah bagaimana kesadaran diri manusia ketika membangun dan menganalisis persoalan apapun di sekitarnya mampu ditumbuhkan oleh pendidikan. Hal seperti itulah yang lebih lanjut lagi dinamakan sebagai cikal bakal konstruktivistik, bentukan atau sebuah konstruksi diri seseorang yang sedang belajar adalah merupakan pengetahuan. Pengetahuan bukan hanya serta merta terberikan (given), akan tetapi juga merupakan sebuah proses yang panjang dan lama. Pengetahuan selanjutnya berada dalam diri manusia sesungguhnya adalah sebuah perjalanan dari seseorang yang mana melakukan kajian pemahaman serta analisis guna bisa dipahami dengan baik. Menurut para konstruktivis, pengetahuan bisa diperoleh secara personal. ${ }^{1}$

Apabila kita lihat di dalam konteks PAI, sudah waktunya di dalam proses pembelajaran PAI yang selama ini digunakan paradigma pengajaran untuk dirubah menjadi paradigma pembelajaran. Paradigma pengajaran PAI sudah bukan menjadi rahasia lagi bahwa selama ini masih penuh akan orientasi pengajaran daripada pembelajaran itu sendiri. Hal itu berdampak kepada pandangan PAI yang acapkali

\footnotetext{
${ }^{1}$ Yamin, Teori Dan Metode Pembelajaran (Malang: Madani, 2014),hal.15.
} 
ditinjau sebagai mata pelajaran yang penuh akan dogma serta pemberian ajaran secara mendalam (indoktrinasi) norma-norma agama yang dalam membukakan kesempatan bagi siswa supaya lebih aktif, kritis, inovatif, dan kreatif di dalam proses kegiatan belajar mengajar di kalangan siswa yang juga masih kurang. Maka tidak mengherankan bahwa apabila dalam mengikuti mata pelajaran PAI siswa menjadi malas dan juga kurang semangat ketika belajar. ${ }^{2}$

Xaviery, dalam hasil studinya sebagaimana dikutip oleh Qowaid, menunjukkan bahwa setidaknya ada tiga pokok permasalahan yang menjadi latar belakang siswa enggan dalam mempelajari mata pelajaran : Pertama, problem tentang teknik atau metode pembelajaran yang tidak menumbuhkan motivasi belajar siswa. Kedua, di dalam eksistensinya, guru bukan bertindak sebagai fasilitator yang membuat siswa belajar, melainkan adalah pribadi yang belajar atau menggurui siswa. Ketiga, media yang kurang interaktif dan atraktif yang digunakan dalam penyampaian pesan pembelajaran. $^{3}$

Satu hal yang merupakan bagian dari prinsip pendidikan yaitu siswa diharuskan aktif membangun pengetahuan dalam pikiran mereka sendiri, bukan malah guru yang memberikan pengetahuannya pada siswa. Berbagai macam konsep belajar dapat dilahirkan dari dalam proses pengembangan model-model pembelajaran. Sehingga telah dikenal saat ini salah satunya yaitu pembelajaran konstruktivistik.

Dalam pandangan psikologi behavioral, teori operant conditioning menjadi dasar di dalam modifikasi perilaku berdasarkan perpaduan antara beberapa penelitian yang menjadi dasar bagi pendekatan konstruktivistik di dalam pembelajaran. Hal tersebut memiliki dasar sebagai premis bahwa individu secara aktif harus "membangun" pengetahuan dan keterampilannya serta dalam proses membangun suatu kerangka dari lingkungan yang ada di luar dirinya oleh siswa diperoleh dari informasi yang ada.

Selanjutnya, pendekatan konstruktivistik yang di dalamnya digunakan prinsipprinsip pembelajaran telah melahirkan berbagai macam pola atau model pembelajaran. Dalam proses belajar, siswa adalah sebagai pelaku aktif kegiatan belajar

2 Qowaid, Dkk. Inovasi Pembelajaran PAI, (Jakarta: Pena Citrasatria, 2006),hal.6.

3 Ibid., hal. 7. 
yang berdasarkan berbagai pengalaman yang mereka miliki, mereka membangun sendiri pengetahuannya. Hal tersebut merupakan pandangan yang sama tentang proses belajar siswa dari berbagai pandangan itu. Pengembangan sistem dalam pembelajaran PAI perlu adanya jasa ilmu pembelajaran pada umumnya. Upaya dalam adaptasi terhadap perkembangan pembelajaran yang disertai identifikasi sesuai dengan karakteristik PAI itu sendiri perlu juga ada di dalam pengembangan sistem pembelajaran PAI. ${ }^{4}$ Dalam psikologi pendidikan, salah satu prinsip yang urgen di dalam teori konstruktivistik yakni bahwa guru tidak hanya sekadar memberi pengetahuan pada siswa. Tetapi siswa juga harus mampu membangun sendiri pengetahuan di dalam benak mereka. ${ }^{5}$

Oleh karena itu, proses pembelajaran di SMPN 9 Yogyakarta mampu mendorong siswa dalam mengorganisasikan pengalamannya menjadi sebuah pengetahuan yang bermakna karena telah dirancang dan dikelola dengan baik. Jadi, dalam membangun constructive habits of mind sangatlah penting peran dari siswa dalam konstruktivistik ini. Supaya siswa memiliki kebiasaan berpikir, maka dibutuhkanlah kebebasan dan juga sikap belajar. Teori belajar yang mencerminkan siswa mempunyai kebebasan berarti siswa mampu memanfaatkan teknik belajar apa saja asalkan tujuan belajar dapat tercapai.

\section{METODE PENELITIAN}

Penelitian ini merupakan jenis penelitian yang sifatnya deskriptif kualitatif, yang memiliki arti bahwa pelaksanaan dalam penelitian ini dengan menetapkan terlebih dahulu apa dan/atau siapa yang akan dijadikan sumber data atau subjek di dalam penelitian, dan juga instrumen apa yang dipakai atau diperlukan dalam pengumpulan data. ${ }^{6}$

Pengumpulan data dalam penelitian ini menggunakan tiga teknik, yaitu observasi, wawancara dan dokumentasi. Sedangkan analisis data dalam penelitian ini

\footnotetext{
${ }^{4}$ Baharuddin dan Esa Wahyuni, Teori Belajar Dan Pembelajaran (Yogyakarta: Ar- Ruzz Media, 2007), hal. 155.

5 Trianto, Model-Model Pembelajaran Inovatif Berorientasi Kontruktivistik, (Jakarta: Prestasi Pustakarya, 2007), hal. 15.

${ }^{6}$ Mohammad Ali, Strategi Penelitian Pendidikan (Bandung: Angkasa, 1993), hal. 153 .
} 
dilakukan secara terus menerus sejak saat pengumpulan data. Adapun langkahlangkah analisis data yang digunakan oleh penulis di dalam penelitian ini yaitu menggunakan analisis data seperti Milles dan Hubberman, yakni reduksi data, penyajian data, serta penarikan kesimpulan.

\section{HASIL DAN PEMBAHASAN}

\section{A. Konstruktivistik Menurut Jerome Bruner}

Pembentukan pengetahuan yang lebih difokuskan daripada penyampaian dan penyimpanan pengetahuan sebagai suatu epistemologi tentang perolehan pengetahuan (knowledge acquisition) merupakan arti dari konstruktivistik. ${ }^{8}$ Dalam rangka memperbaiki pendidikan seyogyanya diketahui terlebih dahulu bagaimana cara manusia belajar dan bagaimana cara pembelajarannya. Pengetahuan seseorang dapat disebut sebagai sebuah konstruksi (bentukan) daripada dirinya.

Pengetahuan bukan saja sekumpulan dari fakta akan suatu kenyataan yang sedang dipelajari, akan tetapi sebagai konstruksi kognitif dari seseorang terhadap suatu objek, pengalaman, dan juga lingkungannya. Sesuatu yang sudah ada dan tersedia sementara orang lain hanya tinggal menerimanya juga bukanlah merupakan pengetahuan, akan tetapi pengetahuan dapat diartikan menjadi suatu pembentukan yang secara terus menerus oleh seseorang yang setiap waktu mengalamai reorganisasi karena adanya berbagai pemahaman baru. ${ }^{9}$

Teori belajar konstruktivistik Jerome Bruner, dapat dikatakan juga dengan teori belajar penemuan. Menurut M. Hosnan (2014), terdapat setidaknya empat hal yang menjadi pokok berkaitan dengan teori Bruner (dalam Carlin \& Sund, 1975), yakni: ${ }^{10}$

${ }^{7}$ Matthew B. Miles dan A. Michael Huberman, Analisis Data Kualitatif: Buku Sumber Tentang Metode-Metode Baru, Penerjemah: Rohendi Rohidi, ed. by UI Press (Jakarta, 1992), hal. 15-18.

${ }^{8}$ Rofiatul Hosna, "Pembelajaran Konstruktivistik Dalam Meningkatkan Penguasaan Agama Siswa Pada Program ILD (Al Ihya Li Ulumi Ad Din) Di MTs An-Nur Pamekasan Madura"”, Jurnal Discovery: Jurnal Ilmu Pengetahuan, J4.01 (2019), hal, 4.

${ }_{9}$ Sumarsih, “Implementasi Teori Pembelajaran Konstruktivistik Dalam Pembelajaran Mata Kuliah Dasar-Dasar Bisnis"”, Jurnal Pendidikan Akuntansi Indonesia, Vol. VIII.No. 1 (2009).

${ }^{10}$ M. Hosman, Strategi Pembelajaran Di Kelas (Bandung: Raja Grafindo, 2014), hal. 35. 
Pertama, individu hanya belajar dan mengembangkan pikirannya apabila ia menggunakan pikirannya. Kedua, dengan melakukan proses-proses kognitif dalam penemuan, siswa akan memperoleh sensasi dan kepuasan intelektual yang merupakan suatu penghargaan intrinsik. Ketiga, satu-satunya cara agar seseorang dapat mempelajari teknik-teknik dalam melakukan penemuan adalah ia memiliki kesempatan untuk melakukan penemuan. Keempat, dengan melakukan penemuan maka akan memperkuat retensi ingatan.

Empat hal di atas juga sesuai dengan proses kognitif yang diperlukan seperti di dalam proses pembelajaran PAI yang saat ini menggunakan kurikulum 2013 dengan metode saintifik.

Menurut Dadang Supardan, mengkonstruksi pengetahuan dengan berdasar pada pengalaman individu dengan interaksi sosial, di mana pengetahuan direfleksikan dari dunia luar yang kemudian disaring melalui serta dipengaruhi oleh bahasa, budaya, keyakinan, interaksi dengan orang lain, modeling, dan pelajaran langsung. ${ }^{11}$ Jerome Bruner memiliki pandangan lain yang berlainan pendapat dari Piaget dan Vygotsky, Bruner mengatakan dalam teorinya itu memiliki asumsi bahwa pertumbuhan kognitif dapat berlangsung dari dalam ke luar dan juga dari luar ke dalam. Dampak yang mendalam dimunculkan dari asumsi yang demikian itu, pada cara memahami pertumbuhan dan keahlian intelektual anak, bagaimana cara anak diajar, belajar, baik dalam keadaan formal maupun dalam keadaan informal. Apabila disimpulkan, Bruner memiliki sebagian asumsi yang mempunyai kemiripan terhadap asumsi pada pendekatan etologi, yaitu kecenderungan dalam berperilaku dengan cara tertentu yang diwarisi oleh manusia. Cara tersebut dapat berasal dari para generasi terdahulu yang berdasar pada latar evolusi dan biologi manusia. Lebih lanjut perkembangan pada diri manusia menurut Bruner adalah bersifat unik yang memiliki arti berbeda daripada hewan-hewan lainnya dikarenakan ada konteks kultural pada tempat di mana perkembangan manusia terjadi. ${ }^{12}$

Selanjutnya, seperti di dunia Barat yang memiliki kultur-kultur yang canggih, batas-batas pertumbuhan bergantung pada seberapa baik kultur yang mendukung

11 Dadang Supardan, “Teori Dan Praktik Pendekatan Konstruktivisme Dalam Pembelajaran"”, Jurnal Edunomic, Volume 4.No.1 (2015), hal, 5.

12 Ibid., hal. 5-6. 
proses perkembangan. Misalnya, seberapa baik proses pembelajaran memberikan misteri dan tantangan ke hadapan anak? Melalui cara dan/atau metode apa pengajaran memberikan penyajian materi-materi itu? Juga, pertumbuhan intelektual dan perubahan kemampuan itu apakah yang diharapkan? Berangkat dari asumsi Jerome Bruner mengenai perkembangan intelektual, disudutkan dan dibatasi oleh kultur, maka tak heran apabila Bruner kemudian berpendapat kita belum membuka apa yang menjadi keran potensi kita pada titik ini. Menurut pandangan Bruner, bahwa hal lain yang sangat penting ketika pembelajaran berlangsung dalam konteks formal, misal di sekolah-sekolah, bahkan dengan sarana informal yang sifatnya tidak langsung, demikian pembelajaran menjadi kehilangan apa yang menjadi sebagian efektivitasnya. Hal tersebut dapat terjadi karena anak-anak diminta memahami berbagai kejadian yang telah terlepas oleh konteks yang melingkupi kejadian tersebut. $^{13}$

Lebih lanjut menurut Bruner, yang dimaksud dengan pembelajaran ialah pelajar yang membina ide baru dengan berdasarkan pengetahuan yang lalu dengan proses yang aktif. Bruner juga menjelaskan bahwa bahan kajian yang diajarkan kepada siswa adalah supaya siswa dibuat mampu untuk berpikir bagi diri mereka sendiri, dan ikut ambil bagian dalam proses pengetahuan itu didapatkan. Kemudian menurut Bruner, yang dimaksud dengan "mengetahui" adalah prosesnya dan bukan merupakan produknya. ${ }^{14}$

Bruner lebih lanjut mengatakan, bahwa pengetahuan dibangun dengan mendasarkan pada dua asumsi yaitu; Pertama, pengetahuan diperoleh sebagai suatu proses interaktif yakni orang yang belajar dan berinteraksi terhadap lingkungannya dengan aktif, di lingkungan itu perubahan tidak hanya terjadi, akan tetapi ada di dalam diri orang tersebut juga. Kedua, yaitu pengetahuan yang dikonstruksi oleh orang dengan informasi yang tersimpan dan yang sebelumnya telah diperoleh kemudian dihubungkan dengan informasi yang masuk. Pandangan Bruner terhadap proses belajar, memandang bahwa proses belajar ditekankan oleh adanya pengaruh kebudayaan dari tingkah laku seseorang. Menurut Bruner, dengan memahami arti,

\footnotetext{
${ }^{13}$ Ibid., hal. 6.

${ }^{14}$ Ratna Wilis Dahar, Teori-Teori Belajar (Jakarta: Erlangga, 1989), hal, 35.
} 
konsep, dan hubungan yang kemudian sampai kepada suatu kesimpulan adalah juga merupakan cara belajar yang terbaik.

Bruner, dalam free discovery learning yang merupakan teorinya, mengungkapkan bahwa apabila kesempatan siswa untuk menemukan suatu teori, konsep, pemahaman, atau aturan melalui contoh-contoh yang dijumpai dalam kehidupannya diberikan oleh guru, maka proses belajar akan berjalan kreatif dan berjalan dengan baik. ${ }^{15}$

Berikut ini merupakan ciri-ciri pembelajaran konstruktivistik; Pertama, mengembangkan ide peserta didik dan menggunakannya sebagai panduan dalam merancang pelajaran. Kedua, mendorong peseta didik supaya bertanya dan untuk berdiaolog dengan guru maupun peserta didik lainnya. Ketiga, menganggap pembelajaran yakni sebagai suatu proses yang sama penting dengan hasil pembelajaran. Keempat, memberikan peluang untuk siswa guna menggali pengetahuan baru dengan memahaminya melalui keterlibatan siswa terhadap situasi dunia yang sebenarnya. ${ }^{16}$

Menurut Mahisa Alit di dalam bukunya, sebagaimana dikutip oleh Indah Sih Prihartini menjelaskan bahwa yang merupakan ciri-ciri dari model pembelajaran konstruktivistik adalah: ${ }^{17}$

a. Pengalaman belajar disediakan dengan mengaitkan pengetahuan yang sudah dimiliki oleh siswa sebelumnya, sehingga belajar dapat dilakukan melalui proses pembentukan pengetahuan.

b. Berbagai macam alternatif pengalaman belajar disediakan, dan tidak semuanya mengerjakan tugas yang sama, misalnya suatu problem dapat diselesaikan dengan berbagai macam cara.

c. Situasi pembelajaran dengan realistik dan relevan dan diintegrasikan dengan melibatkan pengalaman konkret, misal dalam melalui kenyataan kehidupan seharihari dapat dipahami konsep.

${ }^{15}$ C.A Budiningsih, Belajar Dan Pembelajaran, (Jakarta: Rineka Cipta, 2005), hal.43.

16 Indah Sih Prihatini, "Implementasi Model Pembelajaran Konstruktivistik Pada Mata Pelajaran Pendidikan Agama Islam Di SDN Babatagung Deket Lamongan", Jurnal Akademika, Volume 10.Nomor 02 (2016), hal. 208.

${ }^{17}$ Ibid., hal. 208-209. 
d. Pembelajaran diintegrasikan supaya transmisi sosial memungkinkan untuk terjadi yakni interaksi dan kerja sama antara seseorang dengan orang lain memungkinkan terjadi atau pun dengan lingkungannya, misal dalam interaksi dan kerja sama antara siswa, guru, dan siswa lainnya.

e. Berbagai macam media dimanfaatkan termasuk komunikasi lisan dan tertulis supaya pembelajaran yang berlangsung dapat menjadi lebih efektif.

f. Siswa dilibatkan secara emosional dan sosial sehingga menjadi menarik bagi siswa dan siswa menjadi bergairah untuk belajar.

Pendekatan kontruktivistik ini, tentunya menuntut pembelajaran tentang pemahaman makna dari literasi baru ini bagi pendidikan Islam sendiri. Hal ini agar siswa mampu menghadapi tantangan global dengan mempersiapkan diri secara kompetensi dan skill yang akan dihadapi, sehingga nilai kebermanfaatan, baik dari pendekatan kontruktivistik dan literasi baru memberikan suatu ilmu pengetahuan yang terbarukan untuk masa depan mereka. Temuan baru (invention) bagi siswa adalah ilmu pengetahuan mengenai era digital dan industri 4.0 dipahami secara seksama, dan memahami nilai dan mempelari proses melalui literasi baru yang merupakan sebuah kebutuhan dan keharusan yang harus disampaikan dalam menghadapi tantangan baru di masa depan. ${ }^{18}$

Pengembangan pembelajaran Pendidikan Agama Islam (PAI) telah dilakukan sebagai salah satu upaya yang dilaksanakan di SMPN 9 Yogyakarta yakni gaya pembelajaran yang dilakukan adaptasi melalui pendekatan konstruktivistik yang berkaitan dengan karakteristik daripada implementasi pada mata pelajaran Pendidikan Agama Islam itu sendiri.

\section{B. Implementasi dari Model Pembelajaran Konstruktivistik dalam Mata Pelajaran PAI Kelas VII}

Ketika memulai pembelajaran di kelas, guru memulainya dengan mengucap salam, menyapa siswa, dan berdoa bersama. Selanjutnya guru melihat dan mengecek siswa yang hadir saat itu. Di awal pembelajaran, guru membutuhkan waktu sekitar 10

${ }^{18}$ Ummu Kulsum, "Pembelajaran Kontruktivistik Berbasis Literasi Baru Dalam Pendidikan Agama Islam"”, Jurnal Darussalam; Jurnal Pendidikan, Komunikasi Dan Pemikiran Hukum Islam, Vol. X,.No 2: 388-404 (2019), hal. 939. 
menit guna mengkondisikan siswa supaya siap untuk proses pembelajaran baik secara fisik maupun mental di dalam pelaksanaan atau mengikuti proses pembelajaran PAI. ${ }^{19}$

Metode yang dipakai oleh guru dalam mengampu mata pelajaran PAI ialah dengan melaksanakan metode diskusi kelompok. Langkah-langkah pembelajaran yang ada dalam metode ini di antaranya; Pertama, apersepsi diadakan oleh guru sebagai kegiatan pendahuluan dengan memberi motivasi supaya siswa lebih meningkat motivasinya dalam mengikuti pembelajaran. Kedua, guru mendorong dan memotivasi siswa supaya mengajukan pertanyaan terkait materi pelajaran yang sedang dipelajari saat itu. Ketiga, guru membentuk kelompok disesuaikan dengan jumlah siswa yang hadir saat itu. Keempat, guru membimbing siswa untuk mendiskusikan materi pelajaran terkait, yakni tentang perkembangan ilmu pengetahuan pada masa Bani Umayah. Kelima, guru bersama dengan siswa merumuskan hasil diskusi secara berkelompok. Keenam, setelah selesainya diskusi kelompok kecil, siswa melanjutkan untuk mempresentasikan hasil diskusi kelompok kecilnya tersebut. Masing-masing kelompok mempresentasikan kehidupan dan biografi tokoh keilmuan pada masa Bani Umayah sesuai dengan jatah tokoh masing-masing. Ketujuh, bagian akhir yang disebut penutup, yakni guru bersama dengan siswa menyimpulkan hasil belajar yang telah diperoleh. Kemudian guru menutup proses pembelajaran dengan berdoa bersama. Kedepalan, sebagai bentuk evaluasi, guru terkadang memberikan tugas yang berkaitan dengan materi. ${ }^{20}$

Dari metode pembelajaran yang digunakan pada pembelajaran di atas sesuai dengan wawancara dengan Ibu Miftakhurrokhmah, S.Pd. selaku guru mata pelajaran Pendidikan Agama Islam :

"Metode pembelajaran di sini sesuai dengan materi pembelajaran saat itu, dan menerapkan pembelajaran yang aktif, kreatif dan menyenangkan. Tetapi terkadang saya menerapkan metode diskusi kelompok. Untuk jumlah kelompok sendiri saya sesuaikan dengan jumlah siswa. Hasil dari diskusi kelompok yang berkaitan dengan materi pelajaran tersebut lalu dipresentasikan oleh siswa. Dalam menerapkannya, guru harus tetap 
membuat situasi sekondusif mungkin agar dari awal hingga akhir siswa dapat menyerap banyak ilmu dan pembelajaran tetap efektif." 21

Dari ungkapan di atas, dapat disimpulkan bahwa dalam pembelajaran PAI supaya tetap berjalan kondusif dan efektif maka guru senantiasa membuat situasi pembelajaran menjadi tetap kondusif selama pelajaran. Metode yang digunakan pun disesuaikan dengan materi pelajaran saat itu.

\section{Faktor Pendukung dan Penghambat Implementasi Model Pembelajaran Kontruktivistik dalam Mata PAI di SMPN 9 Yogyakarta}

1. Faktor Pendukung

Dalam menerapkan pendekatan pembelajaran konstruktivistik, memiliki kelebihan dan kelemahan tersendiri. Demikian halnya dengan penerapan atau implementasi dari pendekatan konstruktivistik tersebut tidak lepas dari adanya faktor pendukung dan penghambat di dalam pelaksanaannya pada mata pelajaran. Adapun faktor pendukung dari implementasi dalam pendekatan konstruktivistik ialah sebagai berikut:

a) Kesesuaian Muatan Materi, Metode Pembelajaran, dan Media Pembelajaran yang Dipakai

Metode pembelajaran yang dipakai pada proses pembelajaran disesuaikan dengan muatan materi, seperti halnya pada mata pelajaran PAI kelas VII, penerapan metodenya yakni menggunakan metode praktik. Meskipun begitu, bukan berarti juga metode yang lainnya tidak dipergunakan, metode ceramah misalnya juga sangat perlu digunakan yang mana waktunya dialokasikan berapa menit guna memberi instruksi atau petunjuk, arahan, dan aba-aba. Lalu dipergunakan juga metode diskusi, dikarenakan hasil dari praktikum siswa diperlukan juga adanya diskusi kelompok guna memecahkan masalah yang dihadapi oleh siswa.

b) Letak Instansi / Lembaga Pendidikan yang Strategis

${ }^{21}$ Hasil Wawancara dengan Ibu Miftakhurrokhmah, S.Pd. selaku guru mata pelajaran PAI pada tanggal 4 November 2019. 
Melalui hasil dari observasi atau pengamatan yang dilakukan oleh peneliti dapat disimpulkan bahwa SMPN 9 Yogyakarta berada di lokasi yang strategis dan juga tergolong efektif untuk pelaksanaan proses belajar mengajar. Lokasi lembaga pendidikan SMPN 9 Yogyakarta sendiri terdapat sebuah masjid yang dapat mendukung dan memudahkan guru saat memberikan pembelajaran PAI seperti praktik sholat, dan lain-lain. Dengan keberadaan sekolah yang memiliki masjid ini tentu dapat mendukung pelaksanaan proses pembelajaran di mana siswa mampu melakukan praktik secara langsung.

\section{Faktor Penghambat}

Ketika memakai model pembelajaran konstruktivistik pada proses pembelajara PAI, hal itu tidak dapat dilepaskan dari persoalan atau permasalahan yang muncul dan dihadapi ketika pelaksanaannya. Permasalahan tersebut diantaranya:

a) Rasa Percaya Diri Siswa Masih Kurang

Rasa percaya diri siswa merupakan kunci utama dalam keberhasilan bagi guru ketika menerapkan pembelajaran konstruktivistik. Pada mulanya, rasa percaya diri siswa di SMPN 9 Yogyakarta masih belum terbangun ketika di awal penggunaan metode pada kelas VII. Permasalahan tersebut sempat disampaikan oleh Ibu Miftakhurrokhmah, S.Pd. dalam sebuah wawancara :

"Menerapkan model pembelajaran konstruktivistik itu ya awalnya susah-susah gampang, pada saat awal siswa belum terbiasa dengan model pembelajaran tersebut, tidak semua anak mampu berpikir kritis untuk mengembangkan dirinya sendiri, dan mereka perlu waktu untuk beradaptasi dengan suasana, metode, maupun hal-hal yang baru." 22

${ }^{22}$ Hasil Wawancara dengan Ibu Miftakhurrokhmah, S.Pd. selaku guru mata pelajaran PAI pada tanggal 4 November 2019. 
Dari hasil wawancara di atas, dapat disimpulkan bahwa faktor penghambat dari implementasi model pembelajaran di SMPN 9 Yogyakarta adalah di awal penerapan metode, siswa masih belum terbiasa dengan metode baru yang diterapkan. Akibatnya siswa memiliki rasa canggung dalam menyampaikan pendapat, mengajukan pertanyaan, dan berdiskusi dengan siswa lainnya.

b) Manajemen Waktu yang Masih Kurang

Melalui hasil observasi, proses pembelajaran PAI dengan memakai pendekatan konstruktivistik sebenarnya dibutuhkan waktu yang cukup lama supaya hasil dari pelaksanaan pembelajaran dapat optimal, namun dalam pelaksanaan di lapangan hanya memiliki alokasi waktu yang terbatas. Pemberian materi pelajaran hanya tersedia waktu satu jam pelajaran yakni 40 menit, penggunaan metode pembelajaran juga telah dirancang sebelumnya, juga di dalamnya termasuk perangkat yang akan menjadi penunjang dalam pembelajaran misalnya penggunaan video, film, slide powerpoint, poster, gambar, dan lain sebagainya.

\section{Upaya dalam Mengatasi Implementasi Pembelajaran Konstruktivistik PAI}

Proses yang berkelanjutan dan terjadinya suatu proses yang secara berkesinambungan merupakan suatu proses belajar. Belajar itu sangatlah penting, namun pada kenyataannya di lapangan terkadang timbul berbagai permasalahan atau persoalan yang menjadi hambatan di proses pelaksanaan belajar tersebut. Hambatan yang demikian itu bisa berasal dari dalam diri siswa maupun dari luar diri siswa. Adanya hambatan itu jika dibiarkan begitu saja dapat mempersulit dan menghambat siswa untuk mencapai tujuan hasil belajar yang optimal atau maksimal. Maka dari itu, harus ada penanganan dan juga solusi yang tepat guna mengatasi hambatan dari berbagai persoalan yang muncul di dalam proses belajar yang dialami oleh siswa tersebut. Berbagai upaya dapat dilakukan antara lain sebagai berikut:

1. Penanaman Karakter dalam Diri Siswa Seperti Rasa Percaya Diri dan Toleransi 
Berdasarkan hasil observasi dan dokumentasi peneliti, di SMPN 9 Yogyakarta terdapat kegiatan ekstrakurikuler Pramuka. Kegiatan Pramuka dapat meningkatkan rasa percaya diri dan toleransi (sikap saling menghargai dan menghormati) dalam diri siswa. Dengan pendidikan kepramukaan itu, siswa ditanamkan nilai-nilai karakter dan juga dasa darma. Berkaitan dengan hal tersebut, di dalam Anggaran Dasar dan Anggaran Rumah Tangga (AD/ART) Gerakan Pramuka disebutkan bahwa:

"Darma Pramuka merupakan landasan gerak bagi Gerakan Pramuka untuk mencapai tujuan pendidikan kepramukaan yang diwujudkan dalam kegiatan untuk mendorong peserta didik manunggal dengan masyarakat, bersikap demokratis, saling menghormati, serta memiliki rasa kebersamaan dan gotong royong.",23

2. Peningkatan Kualitas Guru-Guru Melalui Keikutsertaan dalam Pelatihan, Workshop, dan sebagainya

Pembinaan guru sebagai pendidik untuk menjadi tenaga pendidik yang profesional memiliki tugas untuk merencanakan, melaksanakan pembelajaran, menilai dan mengevaluasi, melakukan bimbingan, latihan, melakukan penelitian, serta pengabdian kepada masyarakat dapat ditempuh dengan dilaksanakannya pelatihan, workshop, dan sebagainya. Hal tersebut dilakukan dalam rangka meningkatkan kualitas pendidikan pada umumnya dan peningkatan kualitas guru pada khususnya.

3. Peningkatan Motivasi Belajar pada Diri Siswa

Motivasi belajar yang ada pada diri siswa adalah termasuk hal yang cukup penting bagi pencapaian prestasi belajar masing-masing siswa. Dalam memelihara, menjaga dan meningkatkan motivasi belajar siswa tersebut salah satunya ialah menjadi tugas dan kewajiban guru supaya motivasi belajar tersebut senantiasa terjaga. Berkaitan dengan hal itu, Ibu Miftakhurrokhmah, S.Pd. selaku guru mata pelajaran PAI sudah berupaya melakukan motivasi

23 Keputusan Musyawarah Nasional X Gerakan Pramuka Tahun 2018 and Nomor: 07/Munas/2018 tentang Anggaran Dasar dan Anggaran Rumah Tangga Gerakan Pramuka, Tim Penyusun (Jakarta: Kwartir Nasional Gerakan Pramuka, 2019), hal. 23.. 
untuk meningkatkan motivasi belajar siswa, sebagaimana diungkapkan sebagai berikut:

"Dalam mengatasi masalah dalam pembelajaran diperlukan keuletan dan kesabaran dalam membimbing anak-anak agar bisa fokus kembali terhadap apa yang mereka pelajari. Namun itu saja belum cukup, suksesnya pembelajaran juga ditentukan dengan memberikan motivasi atau dorongan kepada siswa agar mereka lebih bersemangat lagi dalam belajar. Untuk memotivasi siswa diperlukan metode yang beragam, menciptakan suasana yang kondusif, memberikan tugas yang sesuai dengan porsi siswa, memberikan nasihat kepada siswa, dan memberikan contoh dari tokoh orang yang sudah berhasil dan memberikan motivasi kata-kata yang lebih menarik, quotes misalnya. "24

Dari ungkapan di atas, dapat disimpulkan bahwa motivasi belajar siswa dapat dilakukan dengan diberikan dorongan kepada siswa supaya lebih bersemangat. Ketika terdapat masalah dalam pembelajaran seyogyanya guru membimbing dengan penuh keuletan dan kesabaran.

\section{KESIMPULAN}

Berdasarkan proses analisis data yang diperoleh, maka dapat disimpulkan sebagai berikut; Pertama, implementasi model pembelajaran konstruktivistik pada mata pelajaran PAI kelas VII di SMPN 9 Yogyakarta sudah berjalan baik dan sudah menerapkan prinsip dan langkah-langkah sesuai model pembelajaran konstruktivistik yang ada. Kedua, implementasi pembelajaran konstruktivistik di dalam mata pelajaran PAI kelas VII di SMPN 9 Yogyakarta dalam pelaksanaannya sudah berjalan dengan baik dengan disertai beberapa faktor pendukung, di antaranya kesesuaian muatan materi dengan metode pembelajaran, dan letak lembaga / instansi pendidikan yang strategis. Selain itu, terdapat pula yang menjadi faktor penghambat ketika pelaksanaan model pembelajaran konstruktivistik di dalam mata pelajaran PAI kelas VII di SMPN 9 Yogyakarta yakni rasa percaya diri siswa yang masih kurang ketika awal

${ }^{24}$ Hasil Wawancara dengan Ibu Miftakhurrokhmah, S.Pd. selaku guru mata pelajaran PAI pada tanggal 4 November 2019. 
diterapkannya model pembelajaran konstruktivistik serta manajemen dalam pengalokasian waktu waktu yang masih kurang mencukupi. Ketiga, Upaya mengatasi masalah dalam implementasi dari model pembelajaran konstruktivistik di dalam mata pelajaran PAI kelas VII di SMPN 9 Yogyakarta yaitu membantu menanamkan karakter pada diri siswa seperti rasa percaya diri dan toleransi, peningkatan kualitas guru-guru melalui keikutsertaan dalam pelatihan, workshop, dan sebagainya, serta meningkatkan motivasi belajar pada siswa.

\section{DAFTAR PUSTAKA}

Ali, Mohammad, Strategi Penelitian Pendidikan (Bandung: Angkasa, 1993)

Budiningsih, C.A, Belajar Dan Pembelajaran, (Jakarta: Rineka Cipta, 2005)

Dahar, Ratna Wilis, Teori-Teori Belajar (Jakarta: Erlangga, 1989)

Hosman, M., Strategi Pembelajaran Di Kelas (Bandung: Raja Grafindo, 2014)

Hosna, Rofiatul, “Pembelajaran Konstruktivistik Dalam Meningkatkan Penguasaan Agama Siswa Pada Program ILD (Al Ihya Li Ulumi Ad Din) Di MTs An-Nur Pamekasan Madura"', Jurnal Discovery: Jurnal Ilmu Pengetahuan, J4.01 (2019), hal, 4.

Huberman, Matthew B. Miles dan A. Michael, Analisis Data Kualitatif: Buku Sumber Tentang Metode-Metode Baru, Penerjemah: Rohendi Robidi, ed. by UI Press (Jakarta, 1992)

Indah Sih Prihatini, “'Implementasi Model Pembelajaran Konstruktivistik Pada Mata Pelajaran Pendidikan Agama Islam Di SDN Babatagung Deket Lamongan”,' Jurnal Akademika, Volume 10.Nomor 02 (2016), hal. 208.

Kulsum, Ummu, "Pembelajaran Kontruktivistik Berbasis Literasi Baru Dalam Pendidikan Agama Islam"”, Jurnal Darussalam; Jurnal Pendidikan, Komunikasi Dan Pemikiran Hukum Islam, Vol. X,.No 2: 388-404 (2019), hal. 939.

Keputusan Musyawarah Nasional X Gerakan Pramuka Tahun, and Nomor: 07/Munas/2018 tentang Anggaran Dasar dan Anggaran Rumah Tangga Gerakan Pramuka, Tim Penyusun (Jakarta: Kwartir Nasional Gerakan Pramuka, 2019)

Qowaid, Dkk., Inovasi Pembelajaran PAI, (Jakarta: Pena Citrasatria, 2006)

Sumarsih, "Implementasi Teori Pembelajaran Konstruktivistik Dalam Pembelajaran Mata Kuliah Dasar-Dasar Bisnis", Jurnal Pendidikan Akuntansi Indonesia, Vol. VIII.No. 1 (2009)

Supardan, Dadang, “'Teori Dan Praktik Pendekatan Konstruktivisme Dalam Pembelajaran"”, Jurnal Edunomic, Volume 4.No.1 (2015), hal, 5. 
Wibisono Yudhi Kurniawan

Trianto, Model-Model Pembelajaran Inovatif Berorientasi Kontruktivistik, (Jakarta: Prestasi Pustakarya, 2007)

Wahyuni, Baharuddin dan Esa, Teori Belajar Dan Pembelajaran (Yogyakarta: Ar- Ruzz Media, 2007)

Yamin, Teori Dan Metode Pembelajaran (Malang: Madani, 2014) 